\title{
Effect of Incubation Study of Coffee Husk on the Amendment of Chemical Properties on Acid Soil
}

\author{
Alemnesh Sisay addisu ${ }^{1 *}$, Endashaw Girma Seyoum² \\ ${ }^{1}$ Natural resource management research Program Ethiopian Institute of Agriculture Research Holetta \\ Research Center, Addis Ababa, Ethiopia,
}

${ }^{2}$ Wheat Breeder Crop Research Program Ethiopian Institute of Agriculture Research Holetta Research Center, Addis Ababa, Ethiopia,

*Corresponding Authors: Alemnesh Sisay addisu, Natural resource management research Program Ethiopian Institute of Agriculture Research Holetta Research Center, Addis Ababa, Ethiopia,

\begin{abstract}
Pot experiment incubation study was carried out to investigate the influence of biochar and lime on selected soil chemical properties of Nitisol loam soil with characteristic of high Phosphorus fixation and acidity. The treatments included (control, $10 t h^{-1}$ coffee husk biochar (CHB), $20 t h^{-}$CHB, lime and $10 t h^{-1}$ $\mathrm{CHB}+50 \%$ lime). These were employed in Randomized Complete Block Design with three replications. The studied soil were collected and subjected to analysis of variance and treatment means were compared at the 0.05 probability level using list significant difference test. The results showed that soil pH increased from 4.89 to 6.68 by applying $20 \mathrm{t} \mathrm{h}^{-1} \mathrm{CHB}$ biochar at the same times the exchangeable acidity and acicd cation are reduced significantly and. Moreover, liming significantly $(P \leq 0.05)$ increased Cation Exchange Capacity (CEC) and available Phosphorus. This study stresses the importance of long-term lime experiments on major crops in order to investigate the residual effects and reduce lime costs.
\end{abstract}

Keywords: Incubation, coffee husk biochar, lime, soil acidity,

\section{INTRODUCTION}

Soil acidification is one of a natural process, which can be enhanced either by the activity of humans or in general living things. An example of man-made activity is Industrial and mining activities can lead to soil acidification through acid drains resulting primarily from pyrite oxidation and from acid precipitation caused by the emission of sulfur ( $\mathrm{SOx}$ ) and nitrogen (NOx) gases. The role of chemistry in this area that stay unaffected by industrial pollution, soil acidification is mainly caused by the release of $\mathrm{H}^{+}$ions during the transformation and cycling of $\mathrm{C}, \mathrm{N}$ and $\mathrm{S}$ in managed ecosystems. Soil acidification is not only detriment and also can use itself in several ways: increase of soil acidity or decrease of $\mathrm{pH}$, decrease of base saturation and unbalanced availability of elements in the root environment, or decrease of the acid neutralizing capacity (ANC) of the soil [1].

It is one of the major limiting factors to crop productivity in the major part of highland area of Ethiopia since excessive rainfall coupled with that removes appreciable amounts of exchangeable basic ions like calcium $(\mathrm{Ca})$, magnesium $(\mathrm{Mg})$, sodium $(\mathrm{Na})$ and potassium $(\mathrm{K})$ from the surface of soil [2] as you know Soil acidity and P fixation in the highlands are among the major challenges affecting agricultural productivity and food security (Agegnehu et al., 2015, 2016, 2019).

Fortunately, such problems can be tackled by the application of appropriate fertilizer, addition of lime and biochar as soil improvements. Agricultural liming material is the most common soil management practices whose addition to agricultural soil in moderate amounts may be beneficial as plant nutrients, minimize soil acidification. The beneficial effects of liming soil are neutralization of exchangeable Al, increase $\mathrm{Ca}, \mathrm{Mg}, \mathrm{P}$ and Mo availability, stimulate microbiological activity in soil; improve physical structure of soil by clumping together or flocculation, clay in to more stable aggregates. In the same manner like agricultural lime recent studies have suggested that the soil amended with biochar can potentially enhance plant physiological processes $[3,4,5]$. The term biochar refers to the carbonaceous product obtained by thermal decomposition of plant or animal residue in an oxygen-limited environment and when applied to soil as an amendment [6].It is not only to maintain soil acidity but also to enhance soil fertility and nutrients for plant uptake, enrich plant growth and yield [7]. 
Know a day limestone material is relatively expensive and unaffordable to the Ethiopian farmers; the supply has limited in Ethiopia, and also can only amend exchangeable calcium, magnesium, and phosphorus. Due to this, researchers have recently started using biochar as an alternative soil amendment mechanism. Once to adjust the pyrolysis machine and demonstrate the technology for producer the material locally available, cheaper, environmentally friend compared to limestone and fertilizer. So, the potential of biochar as a soil nutrient amendment, soil acid management in agricultural fields is a recently recognized and yet it is underutilized technology. Therefore, the aims of this study explored the effects of biochar and combination of biochar with lime to soil physicochemical properties and acid saturation under greenhouse condition.

\section{MATERIALS AND MethodS}

\subsection{Soil sampling}

Bulk Soil sample Known pH level or below 5 were collected from on station of Holetta agricultural research center. Soil sample (0-20 cm depth) at five points in zigzag pattern was collected using an auger, core samplers were used for bulk density sampling separately from the place of soil $\mathrm{pH}$ below 5. Coffee husk biochar was collected from Jimma University College of Agriculture and Veterinary Medicine and used for Incubation experiment studies. Before applying soil amendment some collected soil and biochar sample were transferred to plastic trays and break up the large clods to speed up drying for initial laboratory analysis. The sample was air-dried, crushed with mortar and pestle and passed through a $2 \mathrm{~mm}$ opening stainless steel sieve [8] and laboratory analysis was done.

\subsection{Soil physico-chemical Analysis}

All analytical measurement was performed in Agricultural Research Laboratory and also all the chemicals used were of analytical reagent grade. Distilled water was used for all dilutions throughout the study. For each Laboratory analysis use three Replication .bulky density were determined by using oven dry method while soil texture was analyzed by hydrometer after soil soaked by calgon solution and Soil organic carbon content was determined by the method of [9] and organic matter was estimated from the organic carbon content by multiplying the latter by 1.724 factors. Total $\mathrm{N}$ was determined using the micro-Kjeldahl digestion, distillation and titration procedure as described by Bremner and Mulvaney [10]. Soils available P was extracted by the Bray-II method [11] were quantified using spectrophotometer (wave length of $880 \mathrm{~m}$ ) calorimetrically using the mixture of ammonium molybedate, sulphuric acid and potassium antimony tartrate as an indicator. To determine the cation exchange capacity (CEC), the soil samples were first leached with 1M NH4OAC, and excess NH4OAC washed with ethanol and the adsorbed ammonium was replaced by sodium [12]. The CEC was then measured titrimetrically by distillation of ammonia that was displaced by $\mathrm{Na}$ following the micro- Kjeldahl procedure. Total exchangeable acidity was determined by saturating the soil samples with $1 \mathrm{M} \mathrm{KCl}$ solution and titrating with $0.02 \mathrm{M} \mathrm{H}_{2} \mathrm{SO}_{4}$ as described by Rowell [13]. From the same extract, exchangeable $\mathrm{Al}$ in the soil was titrating with a standard dispersed by mechanical stirrer.

\subsection{Laboratory incubation experimental setup}

The air dried soil sample was used in the laboratory incubation experiments and $3 \mathrm{~kg}$ of soil was filled in plastic pots. The treatments were includes at the rate of control without biochar, $10 \mathrm{t} \mathrm{h}^{-1} \mathrm{CHB}, 20 \mathrm{t}$ $\mathrm{h}^{-1} \mathrm{CHB}$, lime and 50\% lime $+10 \mathrm{t} \mathrm{h}^{-1} \mathrm{CHB}$ thoroughly mixed with soil. During the incubation period, the pots were employed in a greenhouse experiment in a randomized complete block design (RCBD). By adding distilled water in to the mixture of soil -biochar maintained at field capacity throughout the incubation period .The treatments were incubated for 60 days and soil $\mathrm{pH}$, Exg-acidty and Excg. $\mathrm{Al}^{+3}$ were analyzed within 15 days interval and other important physico-chemical properties analyzed at the end of 60 days by removing the sample from each treatments since the target of study to observed which treatment at which time neutralized. 
Effect of Incubation Study of Coffee Husk on the Amendment of Chemical Properties on Acid Soil

\section{RESUlts}

Table1. Physico-chemical properties of studied soil and coffee husk biochar before incubation (mean $\pm S D)$

\begin{tabular}{|l|l|l|l|}
\hline Element & Unit & soil & Biochar \\
\hline $\mathrm{BD}$ & $\mathrm{g} \mathrm{cm}^{-3}$ & 1.02 & \\
\hline $\mathrm{pH}$ & Soil $^{\left(\mathrm{H}_{2} \mathrm{O} 1: 2.5\right) \text { biochar }(1: 5)}$ & 4.89 & 11.05 \\
\hline $\mathrm{EC}$ & $\mathrm{dS} \mathrm{m}^{-1}$ & 0.069 & 5.697 \\
\hline Exch acidity & $\mathrm{cmol}_{\mathrm{c}} \mathrm{kg}^{-1}$ & 3.24 & - \\
\hline Exch $\mathrm{Al}^{+3}$ & $\mathrm{cmol}_{\mathrm{c}} \mathrm{kg}^{-}$ & 2.094 & - \\
\hline $\mathrm{CEC}$ & $\mathrm{cmol}_{\mathrm{c}} \mathrm{kg}^{-1}$ & $19.68 \pm 0.11$ & $65.89 \pm 0.183$ \\
\hline OC & $\%$ & 2.28 & 17.29 \\
\hline TN & $\%$ & 0.11 & 0.62 \\
\hline available p & $\mathrm{Ppm}$ & 7 & 1109 \\
\hline Clay & $\%$ & 72.5 & \\
\hline Silt & $\%$ & 17.5 & \\
\hline Sand & $\%$ & 10 & \\
\hline
\end{tabular}

Table1. Treatment effect of coffee husk biochar on soil pH (mean $\pm S D)$

\begin{tabular}{|l|l|l|l|l|l|}
\hline Treatment & & Incubation period & & & \\
\hline & 0 & 15 & 30 & 45 & 60 \\
\hline control & $4.890 \pm 0.02$ & $4.97 \pm 0.02$ & $5.11 \pm 0.08$ & $5.18 \pm 0.02$ & $5.18 \pm 0.09$ \\
\hline $\mathrm{CHB}\left(10 \mathrm{t} \mathrm{h}^{-1}\right)$ & $5.13 \pm 0.03$ & $5.26 \pm 0.02$ & $5.47 \pm 0.03$ & $5.75 \pm 0.03$ & $5.89 \pm 0.1$ \\
\hline $\mathrm{CHB}\left(20 \mathrm{t} \mathrm{h}^{-1}\right)$ & $5.33 \pm 0.01$ & $5.75 \pm 0.01$ & $6.13 \pm 0.06$ & $6.48 \pm 0.01$ & $6.68 \pm 0.02$ \\
\hline Lime & $5.05 \pm 0.02$ & $5.19 \pm 0.09$ & $5.37 \pm 0.06$ & $5.44 \pm 0.01$ & $5.77 \pm 0.06$ \\
\hline $\begin{array}{l}\mathrm{CHB}\left(10 \mathrm{t} \mathrm{h}^{-}\right. \\
\left.{ }^{1}\right)+50 \% \text { lime }\end{array}$ & $5.21 \pm 0.02$ & $5.35 \pm 0.01$ & $5.68 \pm 0.02$ & $5.88 \pm 0.1$ & $5.94 \pm 0.01$ \\
\hline $\mathrm{LSD}(0.05)$ & 0.24 & 0.11 & 0.3 & 0.22 & 0.25 \\
\hline $\mathrm{CV}(\%)$ & 2.4 & 4 & 2.5 & 2.6 & 3 \\
\hline
\end{tabular}

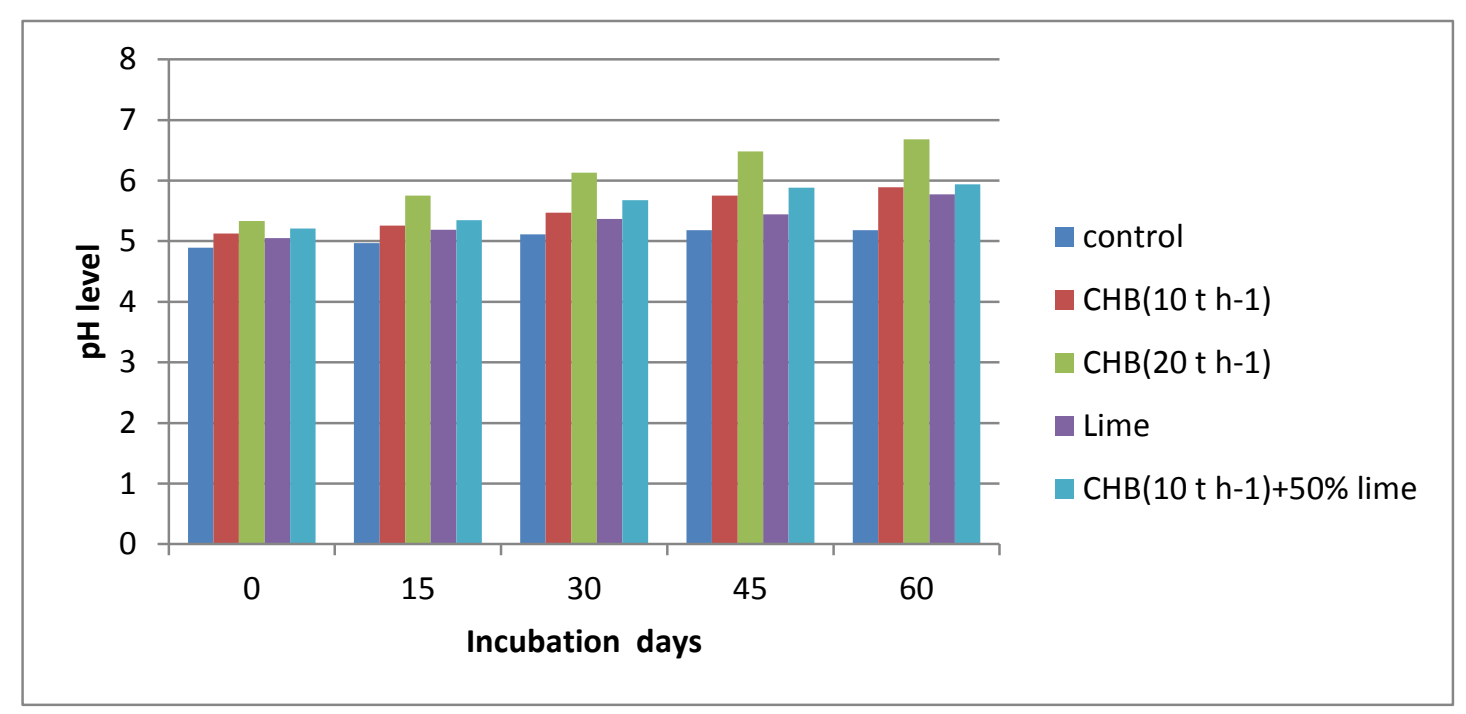

Figure1. Effect of coffee husk biochar on soil pH

Table2. Treatment effect of coffee husk biochar on Exch.acidty (mean $\pm S D$ )

\begin{tabular}{|c|c|c|c|c|c|}
\hline Treatment & \multicolumn{5}{|c|}{ Incubation period } \\
\hline & 0 & 15 & 30 & 45 & 60 \\
\hline control & $3.24 \pm 0.01$ & $3.22 \pm 0.02$ & $3.2 \pm 0.04$ & $3.21 \pm 0.05$ & $3.22 \pm 0.02$ \\
\hline CHB10 th- & $2.92 \pm 0.05$ & $2.45 \pm 0.01$ & $1.95 \pm 0.05$ & $0.74 \pm 0.02$ & $0.22 \pm 0.03$ \\
\hline CHB20 t h- & $2.82 \pm 0.07$ & $1.19 \pm 0.09$ & - & - & - \\
\hline Lime & $3.01 \pm 0.01$ & $2.55 \pm 0.01$ & $2.04 \pm 0.07$ & $1.12 \pm 0.01$ & $0.68 \pm 0.05$ \\
\hline CHB t h-+50\%lime & $2.85 \pm 0.01$ & $2.53 \pm 0.03$ & $0.72 \pm 0.03$ & $0.18 \pm 0.01$ & - \\
\hline $\operatorname{LSD}(0.05)$ & 0.7 & 0.09 & 1.21 & 2.8 & 3.53 \\
\hline $\mathrm{CV}(\%)$ & 4.36 & 1.36 & 2.32 & 3.21 & 2.48 \\
\hline
\end{tabular}




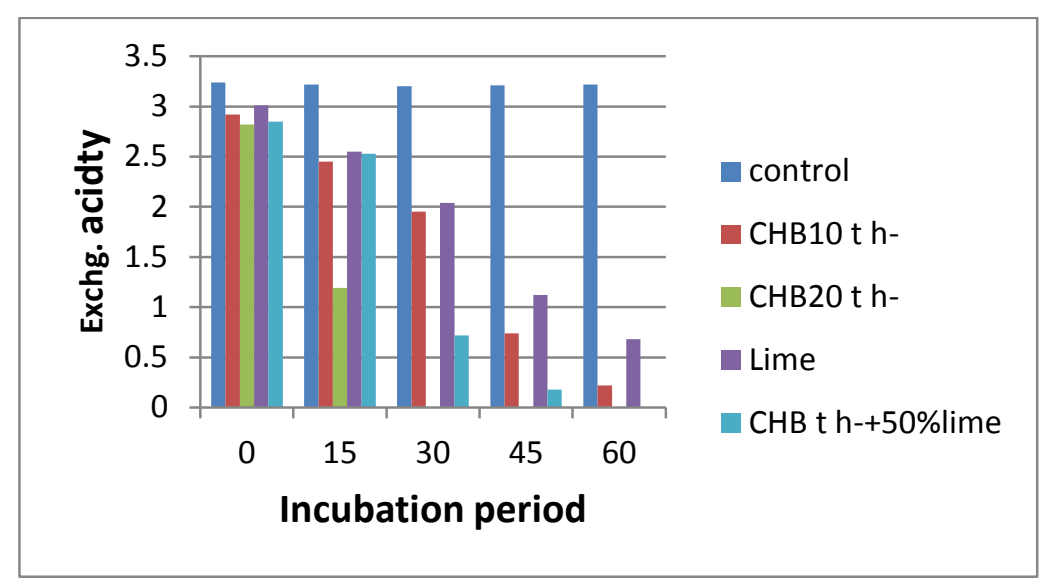

Figure2. Effect of coffee husk biochar on Exch.acidty

Table3. Treatment effect of coffee husk biochar on Exch.Al $l^{+3}$ (mean $\left.\pm S D\right)$

\begin{tabular}{|l|l|l|l|l|l|}
\hline Treatment & \multicolumn{5}{l}{ Incubation period } \\
\hline & 0 & 15 & 30 & 45 & 60 \\
\hline control & $2.12 \pm 0.01$ & $2.1 \pm 0.06$ & $2.0 \pm 0.02$ & $2.0 \pm 0.02$ & $2.12 \pm 0.05$ \\
\hline CHB10 th- & $1.85 \pm 0.03$ & $1.6 \pm 0.01$ & $1.25 \pm 0.04$ & $0.33 \pm 0.05$ & $0.09 \pm 0.05$ \\
\hline CHB20 th- & $1.63 \pm 0.02$ & $0.76 \pm 0.03$ & - & - & - \\
\hline Lime & $1.97 \pm 0.02$ & $1.56 \pm 0.04$ & $1.22 \pm 0.05$ & $0.43 \pm 0.04$ & $0.24 \pm 0.03$ \\
\hline & $1.75 \pm 0.08$ & $1.32 \pm 0.04$ & $0.21 \pm 0.06$ & $0.18 \pm 0.04$ & - \\
\hline LSD (0.05) & 0.8 & 0.75 & 1.3 & 2.14 & 2.35 \\
\hline CV $(\%)$ & 1.21 & 2.18 & 2.82 & 1.6 & 1.53 \\
\hline
\end{tabular}

Table4. Treatment effect of coffee husk biochar on Exch. $H^{+}($mean $\pm S D)$

\begin{tabular}{|l|l|l|l|l|l|}
\hline tretment & \multicolumn{5}{l}{ Incubation period } \\
\hline & 0 & 15 & 30 & 45 & 60 \\
\hline control & $1.12 \pm 0.04$ & $1.12 \pm 0.05$ & $1.2 \pm 0.01$ & $1.21 \pm 0.02$ & $1.1 \pm 0.02$ \\
\hline $\mathrm{CHB}\left(10 \mathrm{t} \mathrm{h}^{-1}\right)$ & $1.07 \pm 0.01$ & $0.85 \pm 0.03$ & $0.7 \pm 0.09$ & $0.41 \pm 0.03$ & $0.13 \pm 0.05$ \\
\hline $\mathrm{CHB}\left(20 \mathrm{t} \mathrm{h}^{-1}\right)$ & $1.19 \pm 0.03$ & $0.43 \pm 0.03$ & - & - & - \\
\hline Lime & $1.04 \pm 0.02$ & $0.99 \pm 0.01$ & $0.82 \pm 0.1$ & $0.69 \pm 0.09$ & $0.44 \pm 0.04$ \\
\hline $\mathrm{CHB}\left(10 \mathrm{t} \mathrm{h}^{-1}+50 \%\right.$ lime $)$ & $1.1 \pm 0.01$ & $1.21 \pm 0.01$ & $0.51 \pm 0.02$ & - & - \\
\hline $\mathrm{LSD}(0.05)$ & 0.07 & 1.2 & 1.5 & 1.33 & 1.32 \\
\hline $\mathrm{CV}(\%)$ & 2.5 & 4.35 & 2.2 & 3,4 & 0.89 \\
\hline
\end{tabular}

Table5. Effect of coffee husk biochar on some selected physico-chemical properties of amended soil

\begin{tabular}{|c|c|c|c|c|c|}
\hline Treatment & $\% \mathrm{OC}$ & $\% \mathrm{OM}$ & $\mathrm{TN}(\%)$ & $\mathrm{P}(\mathrm{ppm})$ & $\mathrm{CEC}(\mathrm{Cmol} / \mathrm{kg})$ \\
\hline Con & $2.76 \pm 0.01^{\mathrm{c}}$ & $4.75 \pm 0.01^{\mathrm{c}}$ & $0.11 \pm 0.0 \mathrm{a}$ & $7.48 \pm 0.75^{\mathrm{e}}$ & $19.65 \pm 0.197^{\mathrm{d}}$ \\
\hline CHB $\left(10 t^{-1}\right)$ & $3.9 \pm 0.002^{b}$ & $6.72 \pm 0.003^{b}$ & $0.11 \pm 0.003^{\mathrm{a}}$ & $9.48 \pm 0.199^{c}$ & $32.89 \pm 1.00 \mathrm{c}$ \\
\hline CHB $\left(20 \mathrm{t} \mathrm{h}^{-1}\right)$ & $5.04 \pm 0.002^{\mathrm{a}}$ & $8.7 \pm 0.11^{\mathrm{a}}$ & $0.11 \pm 0.006^{\mathrm{a}}$ & $13.564 \pm 0.32^{\mathrm{a}}$ & $41.56 \pm 0.9^{\mathrm{a}}$ \\
\hline Lime & $2.78 \pm 0.009^{c}$ & $5.28 \pm 0.016^{\mathrm{c}}$ & $0.113 \pm 0.005^{\mathrm{a}}$ & $8.822 \pm 0.096^{\mathrm{d}}$ & $34.2 \pm 0.08^{c}$ \\
\hline $\begin{array}{l}\text { CHB }\left(10 t^{-1}\right)+ \\
50 \% \text { lime }\end{array}$ & $3.89 \pm 0.06^{\mathrm{b}}$ & $6.71 \pm 0.096^{b}$ & $0.113 \pm 0.008^{\mathrm{a}}$ & $10.944 \pm 0.49^{b}$ & $38.9 \pm 0.05^{\mathrm{b}}$ \\
\hline $\operatorname{LSD}(0.05)$ & 0.12 & 0.12 & NS & 0.471 & 0.562 \\
\hline $\mathrm{CV}(\%)$ & 0.3 & 4.83 & 4.11 & 3.266 & 2.23 \\
\hline
\end{tabular}

\%OC, soil organic carbon; \%OM, soil organic matter; TN, soil total nitrogen; $\mathrm{P}$, soil available phosphorus; CEC, cation exchange capacity; LSD., least significant difference; CV, the coefficient of Variation. Within columns means followed by the same letter are not significantly different at $P=$ 0.05 . 


\section{DISCUSSIONS}

\subsection{Selected physico-chemical properties of studied soil and biochar produced from coffee husk before incubation}

The initial status of soil physico- chemical properties were shown in table 1 . The mean value of soil texture were found to be clay about $(72.5 \%)$, silt $(17.5 \%)$ and sand $(10 \%)$ due to this result indicated the soil texture categorized under clay content(14). In this study, the mean value of soil bulk density was found to be $1.02 \mathrm{~g} / \mathrm{cm} 3$ and its low shown in Table 1 . This is due to high clay contents of soil and Density that occupy small volume [15]. In this finding, the mean value of the initial soil $\mathrm{pH}$ was categorized under strong acidic ( $\mathrm{pH}$ 4.89) [16] similarly from the table 1 the value of Exch.acidty and acid cations $\left(\mathrm{AL}^{+3}\right.$ and $\left.\mathrm{H}^{+}\right)$were categorized under toxic level [17]. The other properties of soil status of organic carbon, total nitrogen, CEC and available phosphors were very low as shown in table 1 this is due to the fixation of those elements expected in acid soil. The biochar results indicated that as used for the amendment of soil has strong alkaline $(\mathrm{pH}, 11.05)$. High electrical conductivity value $(5.693 \pm$ $0.13 \mathrm{dS} / \mathrm{m})$ and $\mathrm{CEC}$ of $65.89 \pm 0.183 \mathrm{Cmol}(+) \mathrm{kg}-1$ was observed in biochar. No detectable exchangeable acidity and exchangeable aluminum were observed in the biochar sample. In this study, the biochar carbon content was (17. 29\%) and the values of available K (243 cmol (+) kg -1), P (1109 $\mathrm{ppm}$ ) is approximately similar with the report of our finding with which is observed by [18]

\subsection{Effect of coffee husk Biochar and lime on selected Soil physico-chemical properties}

The changes in soil $\mathrm{pH}$ due to addition of treatments during 60 days of incubation period are presented in Table 2 and Figuer1. Soil pH known as potential of hydrogen is a specific that describes the relative acidity or alkalinity of the soil. $\mathrm{pH}$ is defined as the negative (-) $\log$ or base 10 value of the concentration of hydrogen ions $[19,20]$. soil $\mathrm{pH}$ influences some soil parameters (soil quality) that affect plant growth and yield; these include soil bacteria, nutrient leaching, nutrient availability, toxic elements and soil structure [21] .Our findings indicate that application of all amendments except control has showed significantly positive effect since; initially the soil $\mathrm{pH}$ was 4.89 due to the addition of treatment the $\mathrm{pH}$ was found increase at all days of incubation. Increase both incubation period and the rate of application of biochar alone and combined together with lime correspondingly increases the soil $\mathrm{pH}$. From this the highest value obtained in $20 \mathrm{t} \mathrm{h}^{-1} \mathrm{CHB}$ at the end of Incubation period. From the graph 1 observing from 0 up to 45 incubation periods the application of lime enhanced the $\mathrm{pH}$ value slowly as compared to $10 \mathrm{t} \mathrm{h}-1 \mathrm{CHB}$ alone. When 10 th-1 CHB with $50 \%$ lime increased significantly the $\mathrm{pH}$ value next to $20 \mathrm{th}$ CHB. This positive effect of treatment and incubation time it may be due to Lime materials is very slowly soluble in water, if the material easily soluble to facilitates speed of reaction between lime and water and carbon dioxide in soil to yield bicarbonate (HCO3 -), which is able to take $\mathrm{H}+$ and $\mathrm{Al} 3+$ (acid-forming cations) out of solution, thereby raising the soil $\mathrm{pH}$. Correspondingly this amendment not only $\mathrm{pH}$ change can also amend Exch.acidty and acid cations ( $\mathrm{Al}+3$ and $\mathrm{H}+$ ) as show figure 2, table 3, 4, 5. Exchangeable acidity is the combnation of $\mathrm{H}^{+}$and $\mathrm{Al}^{3+}$ ions reserved or fixed on soil colloid after the active acidity is measured [22] . When the exchangeable acidity of the soil is high with a resultant low $\mathrm{pH}$, it affects the soil condition and many processes in the soil. In an acidic condition, aluminum fixes phosphorus causing its deficiency in plants roots [23], the bioavailability of iron, aluminum, or manganese can be very high and may reach toxic levels at lower $\mathrm{pH}$ [24]. In other wards both $\mathrm{pH}$ and exchangeable acidity negative relationship as soil $\mathrm{pH}$ increased to reduce acid cations. This result indicated that drastic change due to the process of acid neutralization reaction takes place between soil surface and soil amendments When addition of coffee husk biochar alone and combined with lime they form strong bonds known as chelates with aluminum and this gives rise to the reduction of the solubility of aluminum and soil acidity.. Our finding agrees to [18] who reported days of incubation significantly affected soil $\mathrm{pH}$.

There is no much significant change was observed between lime and control on the value of organic carbon $(2.76,2.78)$ respectively (table 6) similarly between $10 \mathrm{t} \mathrm{h}-1 \mathrm{CHB}$ and $10 \mathrm{t} \mathrm{h} \mathrm{CHB}+50 \%$ lime also no significant change on OC content at the last incubation days (3.9 and 3.89) respectively. Whereas significant difference was observed at $20 \mathrm{t} \mathrm{h} \mathrm{CHB} \mathrm{(5.04)} \mathrm{and} \mathrm{this} \mathrm{significant} \mathrm{change} \mathrm{due} \mathrm{to}$ the addition of biochar could result from the presence of a high amount of organic matter.

Availability of Phosphorous is significantly affected by soil acidity. The phosphorous concentration is found to be increased after application of treatments at 60 day incubation period (Table 6). This is due to either the nature of existence of phosphorous in soil or due to the presence of concentration of 
phosphorous in the biochar. The existence of $\mathrm{P}$ is extremely limited by soil $\mathrm{pH}$. At $\mathrm{pH}<5.5 \mathrm{P}$ is fixed by $\mathrm{Al}^{+3}$ and $\mathrm{Fe}^{+3}$ in the form of AlPO4 and $\mathrm{FePO} 4$, while at $\mathrm{pH}>5.5$ it exists in the form of $\mathrm{Ca}_{3}(\mathrm{PO} 4)_{2}$ On the other hand, there is a high competition between acid cations such as $\mathrm{Al}+3, \mathrm{Fe}+3$ and basic cations such as $\mathrm{Na}+, \mathrm{K}+, \mathrm{Ca}^{+2}$ and $\mathrm{Mg}^{+2}$ to be bonded to $\mathrm{PO}^{-3}$ during this time phosphors could not be Absorbed by plant roots [25].phosphors is the primary nutrient for all plants and uptake in the form of $\mathrm{PO}^{-3}$. In this study the concentration of phosphorus was found between the range of 7.48- 13.56 in all treatment and at the last day of incubation. High value was observed in the application of $20 \mathrm{t} \mathrm{h}^{-1}$ of CHB (Table 6).

Cation exchange sites are found primarily on clay minerals and organic matter (OM) surfaces. Soil $\mathrm{OM}$ will develop a greater CEC at near-neutral $\mathrm{pH}$ than under acidic conditions ( $\mathrm{pH}$-dependent CEC) in other words both $\mathrm{CEC}$ and $\mathrm{pH}$ positive correlations as $\mathrm{pH}$ rise with CEC increase. In our study the content of CEC indicate that highly significant change at all treatment after 60 days incubation period than the control as shown in Table 6. Significantly higher soil CEC contents were obtained from $20 \mathrm{t}$ h-1 CHB, 10 t h-1 CHB + $50 \%$ lime, and recommended lime than $10 \mathrm{t} \mathrm{h}-1 \mathrm{CHB}$ alone $(41.56,38.9$, and 34.2) respectively. The positive effect of the application of biochar and lime indicated that might be due to the high surface area of biochar could increase cation exchange capacity and enhance the ability of soils to retain and Supply nutrients and improved soil conditions such as soil $\mathrm{pH}$ and Reduction of exchangeable acidity which in turn increased the exchange sites of the soil respectively.

\section{Conclusions}

Application of biochar alone and combined with lime resulted in positive effect on soil chemical properties. In highly acidic soils it may serve as a soil amendment by increasing the soil $\mathrm{pH}, \mathrm{P}$ availability, CEC and SOC in a sustainable manner. From all treatment plant nutrient (soil chemical) property highly significant result obtained at applying $20 \mathrm{t} \mathrm{h}^{-1} \mathrm{CHB}$ and next $10 \mathrm{t} \mathrm{h}^{-1} \mathrm{CHB}$

After 60 days greenhouse incubation of biochar alone and combined with lime attain the target $\mathrm{pH}$ 6.68 and decrease in both exchangeable acidity and $\mathrm{Al}$ to undetectable $\mathrm{cmol} / \mathrm{Kg}$. During application of treatment, soil $\mathrm{pH}$ increases slightly in the first incubation period and fastly increases the last two months due to a slight decrease in the strengths of acidity as liming period increases. So, the farmer must be to give incubation period after applying the treatment of acid soil management before show his/her seeds. This is due to the reaction between materials and soil acidity is time dependent reaction. Therefore this is particular importance as it indicates the value of biochar as alternative amendments to ameliorate acid soil management for small-scale farmers who cannot afford to regularly purchase lime and mineral fertilizers.

Generally, all the result of soil nutrient obtained with the acceptable analytical methods which were evaluated by analytical method validation and quality control parameters such as precision accuracy, reliability by measurements of replication, method blank, spike recovery was taken

\section{REFERENCES}

[1] van Breemen N (1991) Soil acidifi cation and alkalisation. In "Soil Acidity” (B. Sumner, Eds.), 1-7. Link: https://bit.ly/2GmvgZe

Ulrich, and M. E.

[2] Rowell, D. L., 1994. Soil Science: Methods and Application, Addison Wesley England.

Longman, Limited

[3] Agegnehu, G., Bass, A. M., Nelson, P. N., Muirhead, B., Wright, G., \& Bird, M. I. (2015). Biochar and biochar-compost as soil amendments: effects on peanut yield, soil properties and greenhouse gas emissions in tropical North Queensland, Australia. Agriculture, Ecosystems \& Environment, 213, 72-85.

[4] Agegnehu, G., \&Woldesenbet, F. (2016).Production of biodegradable plastic by polyhydroxybutyrate (PHB) accumulating bacteria using low-cost agricultural waste material.BMC research notes, 9(1), 509.

[5] Akhtar, S. S., Li, G., Andersen, M. N., \& Liu, F. (2014).Biochar enhances yield and quality of tomato under reduced irrigation. Agricultural Water Management, 138, 37-44.

[6] Maia, C. M. B., Madari, B. E., \& Novotny, E. H. (2011). Advances in biochar research in Brazil. Embrapa Solos-Artigoemperiódicoindexado (ALICE). 75

[7] Major, J., Rondon, M., Molina, D., Riha, S. J., \& Lehmann, J. (2010).Maize yield and nutrition during 4 years after biochar application to a Colombian savanna oxisol.Plant and soil, 333(1-2), 117-128. 
[8] Reeuwijk, LP van (2002).Technical paper in procedures in soil analysis.6th edition Walkey, A. and Black, I.A. (1934).An examination of Degtjareff method for determining soil Bremner, J. M. and C. S. Mulvaney, (1982). Nitrogen- Total.In: Page, A. L., R. H. Miller and D. R. Keeney (eds). Methods of Soil Analysis, Part 2. American Society Agronomy. Madison, Wiscosin, pp: 595-624.

[9] Bray, R.. (1945). Determination of total organic and available phosphorous in soil (4th edttion.). London: London Academic Press.

[10] Sosulski, T. (2004). Estimation of liming and gypsum conservation division, USDA handbook No. 18.Usapplication on the content of exchangeable aluminum government printing office. Washington, D. C,: USA in sandy soil (in Polish).

[11] Taye, B. (2008). Estimation of Lime Requirment. Training Manual for Regional Soil Testing Laboratory Heads and Technicians. National Soil Testing Center, Ministry of Agriculture and Rural Development.

[12] Van Lierop, W. (1991). Testing soils for $\mathrm{pH}$ and lime requirement. New York: Soil Science Society American Process.

[13] Desta, B. (2002). Effect of Liming and N and P Fertilization on Grain Yield of Barley in Ethiopian. Journal of Agricultural SciencesVol. 15) pp. 11-15.

[14] Tekalign, M., \&Haque, I. (1991).Phosphorus status of some Ethiopian soils. III. Evaluation of soil test methods for available phosphorus. Trop. Agric, 68, 51-56.

[15] Sosulski, T. (2004). Estimation of liming and gypsum conservation division, USDA handbook No. 18. Usapplication on the content of exchangeable aluminum government printing office. Washington, D. C,: USA in sandy soil (in Polish).

[16]Dume, B., Ayele, D., Regassa, A., \&Barecha, G. (2016). Interactive effects of biochar in soil related to feedstock and pyrolysis temperature. American-Eurasian J Agric Environ Sci, 16, 442-448.

[17] McCauley, A., Jones, C. and Jacobsen, J. (2009) Nutrient Management. Module No. 8, Montana State University Extension Publications.

[18] Benton, J.J. (2012) Plant Nutrition and Fertility Manual. 2nd Edition, CRC Press, Taylor and Francis Group, Florida, 27.Perry, L. (2015) pH for the Garden

[19] McCarty, L.B., Rodriguez, I.R., Bunnell, B.T. and Waltz, F.O. (2003) Fundamentals of Turf Grass and Agricultural Chemistry. John Wiley and Sons Inc., Hoboken, New Jersey, 1198.

[20] Thomson, C.J., Marschner, H. and Römheld, V. (1993) Effect of Nitrogen Fertilizer Form on pH of the Bulk Soil and Rhizosphere, and on the Growth, Phosphorus, and Micronutrient Uptake of Bean. Journal of Plant Nutrition, 16, 493-506.

[21]Liu, G., Mylavarapu, R., Hanlon, E. and Lee, C.W. (2014) Soil pH Management for Optimum Commercial Fruit Production in Florida.

[22] Haynes, J. R. (2001). Amelioration of aluminum toxicity and P deficiency in acid soils by additions of organic residues critical review of the phenomenon and the 22 mechanisms involved. Kluwer Academic Publishers Netherlands.

Citation: Alemnesh Sisay addisu, Endashaw Girma Seyoum., (2021). "Effect of Incubation Study of Coffee Husk on the Amendment of Chemical Properties on Acid Soil”, International Journal of Research Studies in Agricultural Sciences (IJRSAS), 7(7), pp. 35-41 DOI: http://dx.doi.org/10.20431/2454-6224.0707004

Copyright: (C) 2021 Authors. This is an open-access article distributed under the terms of the Creative Commons Attribution License, which permits unrestricted use, distribution, and reproduction in any medium, provided the original author and source are credited. 